\title{
ANALISIS KEMAMPUAN PEMAHAMAN KONSEP SISWA DALAM MENYELESAIKAN SOAL-SOAL MATEMATIKA KELAS VIII SMP NEGERI 23 REJANG LEBONG
}

\author{
Atma Nuraziz ${ }^{1}$, Sukasno $^{2}$, Nur Fitriyana ${ }^{3}$ \\ ${ }^{1}$ STKIP PGRI Lubuklinggau, Indonesia, atmanoeraziz@gmail.com \\ ${ }^{2}$ STKIP PGRI Lubuklinggau, Indonesia, sukasno@stkippgri-lubuklinggau.ac.id \\ ${ }^{3}$ STKIP PGRI Lubuklinggau, Indonesia, nurfitriyana@stkippgri-lubuklinggau.ac.id
}

\begin{tabular}{l} 
ARTICLE INFORMATION \\
\hline Received: November 09, 2020 \\
Revised: December 10, 2020 \\
Available online: December 31, 2020 \\
KEYWORDS \\
Pemahaman konsep, Matematika \\
Understanding concepts, \\
Mathematics \\
CORRESPONDENCE
\end{tabular}

\section{Nur Fitriyana}

E-mail: nurfitriyana@stkippgrilubuklinggau.ac.id

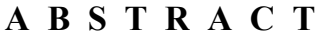

Tujuan penelitian ini untuk mendeskripsikan kemampuan pemahaman konsep siswa dalam menyelesaikan soal-soal matematika di kelas VIII SMP Negeri 23 Rejang Lebong. Penelitian ini menggunakan metode deskriptif kualitatif. Subjek dalam penelitian ini adalah siswa kelas VIII-1 SMP Negeri 23 Rejang Lebong yang terbagi menjadi 3 kelompok, yaitu siswa dengan kemampuan tinggi, kemampuan sedang, dan kemampuan rendah. Teknik pengumpulan data dalam penelitian ini menggunakan teknik tes dan wawancara. Hasil penelitian menunjukkan bahwa persentase ketercapaian setiap indikator kemampuan pemahaman konsep siswa secara keseluruhan terletak pada kriteria cukup sebesar 56,67\%. Dengan rincian tiap-tiap indikator pemahaman konsep sebagai berikut: 1) Indikator menyatakan ulang sebuah konsep sebesar 61,11 \%,2) Indikator memberikan contoh dan bukan contoh sebesar 80,56\%, 3) Indikator mengklasifikasikan objek menurut sifat-sifat tertentu sesuai dengan konsepnya sebesar 40,74\%, 4) Indikator menyajikan konsep dalam bentuk representasi matematis sebesar 53,24 \%, 5) Indikator mengembangkan syarat perlu dan syarat cukup suatu konsep sebesar 64,81 \%, 6) Indikator menggunakan, memanfaatkan dan memilih prosedur atau operasi tertentu sebesar 40,28 \%, dan 7) Indikator mengaplikasikan konsep atau algoritma dalam pemecahan masalah sebesar $66,20 \%$.

The purpose of this research is to describe students' concept comprehension ability in solving math problems in grade VIII of SMP Negeri 23 Rejang Lebong. This research uses descriptive qualitative method. The subjects in this study were grade VIII-1 students of SMP Negeri 23 Rejang Lebong which were divided into 3 groups, namely students with high ability, medium ability, and low ability. Data collection techniques in this study use test and interview techniques. The results showed that the percentage of achievement of each indicator of students' overall concept comprehension ability lies in the criteria of $56.67 \%$. With the details of each concept understanding indicator as follows: 1) The indicator reasates a concept by $61.11 \%$,2) Indicators provide examples and not examples of $80.56 \%$, 3) Indicators classify objects according to certain traits according to their concept of 40.74\%, 4) Indicators present concepts in the form of mathematical representations of 53.24\%, 5) Indicators develop necessary terms and conditions sufficient for a concept of $64.81 \%$, 6) Indicators using, utilizing and selecting certain procedures or operations by $40.28 \%$, and 7) Indicators apply concepts or algorithms in troubleshooting by $66.20 \_\%$. 


\section{Journal of Mathematics Science and Education \\ ISSN (Print) 2623-2375 | ISSN (Online) 2623-2383 | \\ DOI : https://doi.org/10.31540/jmse.v3i1.1037 \\ Penerbit : LP4MK STKIP PGRI Lubuklinggau}

\section{PENDAHULUAN}

Salah satu tujuan dari pembelajaran matemetika dari SD sampai dengan SMA atau sederajat menurut Depdiknas (Septiyana, dkk. 2016:129) diantaranya adalah "siswa dapat memahami konsep matematika, menjelaskan keterkaitan antar konsep dan mengaplikasikan konsep atau algoritma secara luwes, akurat, efisien dan tepat dalam pemecahan masalah". Menurut Hartati, dkk (2017:42) “pemahaman konsep merupakan landasan sangat penting, karena dengan penguasaan konsep akan memudahkan siswa dalam mempelajari matematika". Hal yang sama juga menurut Murizal, dkk (2012:20) "dalam mempelajari matematika peserta didik harus memahami konsep matematika terlebih dahulu agar dapat menyelesaikan soal-soal dan mengaplikasikan pembelajaran tersebut di dunia nyata.” Dengan demikian dapat dikatakan bahwa kemampuan pemahaman konsep merupakan kebutuhan penting dalam mempelajari ilmu matematika agar dapat menyelesaikan soal-soal matematika dan dapat diaplikasikan dalam kehidupan nyata.

Berdasarkan hasil wawancara dengan guru pelajaran matematika yang di SMP Negeri 23 Rejang Lebong pada tanggal 23 April 2020 terkait permasalahan pemahaman konsep matematika siswa, didapatkan informasi bahwa masih terdapat siswa yang kesulitan didalam memilih serta memanfaatkan prosedur hitung dalam menyelesaikan soal hal ini dikarenakan siswa masih kebanyakan menghafal cara penyelesaian soal dari guru dan terlebih lagi ketika soal tersebut berhubungan dengan materi prasyarat sebelumnya. Ditemukan juga siswa yang masih kesulitan dalam menyajikan suatu konsep ke dalam bentuk representasi matematika hal ini sering terjadi pada soal yang berbentuk soal cerita, sehingga untuk menuliskan ke dalam bentuk matematika siswa cenderung salah.

Berdasarkan latar belakang tersebut, peneliti tertarik untuk melakukan penelitiaan dengan judul "Analisis Kemampuan Pemahaman Konsep Siswa dalam Menyelesaikan Soal-Soal Matematika Kelas VIII SMP Negeri 23 Rejang Lebong Tahun Pelajaran 2020/2021”. Tujuan dari penelitian ini adalah untuk mengetahui kemampuan pemahaman konsep siswa dalam menyelesaikan soal-soal matematika di kelas VIII SMP Negeri 23 Rejang Lebong.

\section{METODE}

Penelitian ini dilaksanakan di SMP Negeri 23 Rejang Lebong yang beralamatkan di Jalan Raya Desa IV Suku Menanti Kecamatan Sindang Dataran. Penelitian ini dilaksanakan pada tanggal 10 Agustus s/d 10 September 2020. 


\section{Journal of Mathematics Science and Education \\ ISSN (Print) 2623-2375 | ISSN (Online) 2623-2383 | \\ DOI : https://doi.org/10.31540/jmse.v3i1.1037 \\ Penerbit : LP4MK STKIP PGRI Lubuklinggau}

Metode penelitian yang digunakan dalam penelitian ini adalah metode deskriptif dengan menggunakan pendekatan kualitatif. Menurut Arifin (Lusiana, dkk, 2018;61) "penelitian kualitatif adalah suatu proses penelitian yang dilakukan secara wajar dan natural dengan kondisi objektif di lapangan tanpa adanya manipulatif". Metode deskriptif merupakan metode dalam meneliti status sekelompok manusia, suatu objek, suatu set kondisi, suatu sistem pemikiran, ataupun suatu kelas peristiwa pada masa sekarang. Subjek dalam penelitian ini adalah siswa kelas VIII-1 SMP Negeri 23 Rejang Lebong dan subjek penelitian akan dikelompokkan menjadi 3 kelompok berdasarkan kemampuan kognitif yang dimiliknya yaitu kemampuan kognitif tingkat tinggi, sedang, dan rendah.

Prosedur penelitian kualitatif mendasarkan pada logika berpikir induktif sehingga perencanaannya bersifat sangat fleksibel. Untuk mengetahui kemampuan pemahaman konsep matematika siswa dalam penelitian ini, peneliti menggunakan instrumen berupa soal tes uraian dengan mengikuti pedoman penskoran pemahaman konsep. Penelitian dilanjutkan dengan melakukan observasi yang digunakan untuk melihat dan mencatat secara langsung kemampuan pemahaman konsep siswa pada saat kegiatan belajar mengajar sedang berlangsung dengan tujuan untuk lebih dalam mendiagnosis kemampuan pemahaman konsep matematika. Untuk mengetahui secara lanjut kemampuan pemahaman konsep matematika siswa, maka dilakukan wawancara kepada beberapa subjek penelitian.

Data dalam penelitian ini bersifat data kualitatif, yaitu data yang berbentuk kata-kata bukan dalam bentuk angka atau data yang berupa gambar yang didapatkan dari hasil pemotretan atau rekaman vidoe. Data yang digunakan dalam penelitian ini adalah data hasil tes kemampuan pemahaman konsep, naskah wawancara dengan subjek penelitian dan catatan hasil observasi pada dokumen tes diagnosis kemampuan pemahaman konsep. Dan sumber data dalam penelitian ini, peneliti mengumpulkan data internal dan data eksternal.

Teknik pengumpulan data merupakan cara yang digunakan oleh peneliti untuk mengumpulkan data-data penelitian dari sumber data. Data yang diperoleh dalam penelitian ini adalah dengan cara triangulasi. Triangulasi yang digunakan dalam penelitian ini adalah dengan cara triangulasi teknik.

Analisis data adalah proses mencari dan menyusun secara sistematis data yang diperoleh dari hasil wawancara, catatan lapangan, dan bahan-bahan lainnya, sehingga dapat mudah dipahami, dan temuannya dapat diinformasikan kepada orang lain. Menurut Siyoto dan Sodik (2015:124) secara umum metode analisis data meliputi reduksi, display data, dan kesimpulan atau verifikasi data. Uji 


\section{Journal of Mathematics Science and Education \\ ISSN (Print) 2623-2375 | ISSN (Online) 2623-2383 | \\ DOI : https://doi.org/10.31540/jmse.v3i1.1037 \\ Penerbit : LP4MK STKIP PGRI Lubuklinggau}

keabsahan data dalam penelitian ini meliputi uji kredibilitas, uji transferabilitas, uji dependabilitas, dan uji konfirmabilitas.

\section{HASIL DAN PEMBAHASAN}

\section{Hasil}

Dari hasil tes pemahaman konsep yang peneliti lakukan, peneliti dapat menggolongkan subjek penelitan menjadi 3 kategori yaitu tinggi, sedang dan rendah sesuai dengan tabel berikut:

\begin{tabular}{|c|l|c|c|}
\hline No & \multicolumn{1}{|c|}{ Kategori } & Rentang Skor & Jumlah Subjek \\
\hline 1 & Tinggi & $70<$ skor $\leq 100$ & 5 \\
\hline 2 & Sedang & $30<$ skor $\leq 70$ & 18 \\
\hline 3 & Rendah & $0<$ skor $\leq 30$ & 4 \\
\hline
\end{tabular}

Interprestasi kemampuan pemahaman konsep siswa yang didapat dalam penelitian disajikan pada tabel berikut:

\begin{tabular}{|c|l|c|c|}
\hline No & \multicolumn{1}{|c|}{ Kriteria } & Rentang Skor & Jumlah Subjek \\
\hline 1 & Sangat baik & $85,00-100$ & 2 \\
\hline 2 & Baik & $70,00-84,99$ & 6 \\
\hline 3 & Cukup & $55,00-69,99$ & 9 \\
\hline 4 & Rendah & $40,00-54,99$ & 5 \\
\hline 5 & Sangat rendah & $0,00-39,99$ & 5 \\
\hline
\end{tabular}

Indikator menyatakan ulang sebuah konsep, didapatkan hasil bahwa siswa yang berkemampuan tinggi mampu menyatakan ulang sebuah konsep sebanyak 4 siswa. Siswa dengan kemampuan sedang mampu menyatakan ulang sebanyak 12 siswa. Sedangkan siswa dengan kemampuan rendah tidak ada yang mampu menyatakan ulang sebuah konsep.

Indikator memberikan contoh dan bukan contoh, didapatkan hasil bahwa siswa yang memiliki kemampuan tinggi mampu memberikan contoh dan bukan contoh sebanyak 5 siswa. Siswa dengan kemampuan sedang mampu memberikan contoh dan bukan contoh sebanyak 14 siswa. Sedangkan siswa dengan kemampuan rendah yang mampu memberikan contoh dan bukan contoh sebanyak 2 siswa. 


\section{Journal of Mathematics Science and Education \\ ISSN (Print) 2623-2375 | ISSN (Online) 2623-2383 | \\ DOI : https://doi.org/10.31540/jmse.v3i1.1037 \\ Penerbit : LP4MK STKIP PGRI Lubuklinggau}

Indikator mengklasifikasikan objek menurut sifat-sifat tertentu sesuai dengan konsepnya, didapatkan hasil bahwa siswa yang memiliki kemampuan tinggi mampu mengklasifikasikan objek menurut sifat-sifat tertentu sesuai dengan konsepnya sebanyak 5 siswa. Siswa berkemampuan sedang mampu mengklasifikasikan objek menurut sifat-sifat tertentu sesuai dengan konsepnya sebanyak 5 siswa. Sedangkan siswa berkemampuan rendah belum mampu mengklasifikasikan objek menurut sifat-sifat tertentu sesuai dengan konsepnya.

Indikator menyajikan konsep dalam bentuk representasi matematis, didapatkan hasil bahwa siswa yang memiliki kemampuan tinggi mampu menyajikan konsep dalam bentuk representasi matematis walaupun belum tepat sebanyak 3 siswa. Siswa dengan kemampuan sedang mampu menyajikan konsep dalam bentuk representasi matematis walaupun belum tepat sebanyak 9 siswa. Sedangkan siswa dengan kemampuan rendah tidak ada yang mampu menyajikan konsep dalam bentuk representasi matematis.

Indikator mengembangkan syarat perlu dan syarat cukup, didapatkan hasil bahwa siswa yang memiliki kemampuan tinggi mampu mengembangkan syarat perlu dan syarat cukup sebanyak 5 siswa. Siswa dengan kemampuan sedang mampu mengembangkan syarat perlu dan syarat cukup sebanyak 11 siswa. Sedangkan siswa dengan kemampuan rendah tidak ada satupun yang mampu mengembangkan syarat perlu dan syarat cukup.

Indikator menggunakan, memanfaatkan dan memilih prosedur atau operasi tertentu, didapatkan hasil bahwa siswa yang memiliki kemampuan tinggi mampu menggunakan, memanfaatkan dan memilih prosedur atau operasi tertentu sebanyak 2 siswa. Siswa dengan kemampuan sedang mampu menggunakan, memanfaatkan dan memilih prosedur atau operasi tertentu sebanyak 2 siswa. Sedangkan siswa dengan kemampuan rendah tidak ada yang mampu menggunakan, memanfaatkan dan memilih prosedur atau operasi tertentu.

Indikator mengaplikasikan konsep atau algoritma dalam pemecahan masalah, didapatkan hasil bahwa siswa yang memiliki kemampuan tinggi mampu mengaplikasikan konsep atau algoritma dalam pemecahan masalah sebanyak 2 siswa. Siswa dengan kemampuan sedang mampu mampu mengaplikasikan konsep atau algoritma dalam pemecahan masalah sebanyak 3 siswa. Sedangkan siswa dengan kemampuan rendah tidak ada yang mampu mengaplikasikan konsep atau algoritma dalam pemecahan masalah. 


\section{Journal of Mathematics Science and Education \\ ISSN (Print) 2623-2375 | ISSN (Online) 2623-2383 | \\ DOI : https://doi.org/10.31540/jmse.v3i1.1037 \\ Penerbit : LP4MK STKIP PGRI Lubuklinggau}

\section{Pembahasan}

Deskripsi kemampuan pemahaman konsep matematika siswa SMP Negeri 23 Rejang Lebong dari hasil tes diagnosis kemampuan pemahaman konsep dan hasil wawancara pada tiap-tiap indikator kemampuan pemahaman konsep dideskripsikan sebagai berikut:

Indikator menyatakan ulang sebuah konsep merupakan kemampuan siswa dalam menyatakan konsep yang telah dipelajari ke dalam bentuk yang lain yang dapat siswa pahami sendiri. Dari soal yang diberikan, secara garis besar tingkat ketercapaian indikator menyatakan ulang sebuah konsep matematika siswa kelas VIII-1 dalam kategori cukup yaitu 61,11\%. Adapun rincian dari ketercapaian tersebut adalah 16 siswa dengan persentase ketercapaian $100 \%, 1$ siswa dengan persentase ketercapaian $50 \%$, dan 10 siswa dengan ketercapaian $0 \%$.

Indikator memberikan contoh dan bukan contoh merupakan kemampuan siswa dalam membuat suatu contoh ataupun bukan contoh sesuai dengan konsep yang dipelajari. Dari soal yang diberikan, secara garis besar tingkat ketercapaian indikator memberikan contoh dan bukan contoh siswa kelas VIII-1 dalam katagori baik yaitu 80,56 \%. Adapun rincian dari ketercapaian tersebut adalah 21 siswa dengan persentase ketercapaian $100 \%$, 1 siswa dengan persentase ketercapaian $75 \%$, dan 5 siswa dengan ketercapaian $0 \%$.

Indikator mengklasifikasikan objek menurut sifat-sifat tertentu sesuai dengan konsepnya merupakan kemampuan siswa dalam menggolongkan objek-objek ke dalam suatu kelompok konsep secara keseluruhan. Dari soal yang diberikan, secara garis besar tingkat ketercapaian mengklasifikasikan objek menurut sifat-sifat tertentu sesuai dengan konsep siswa kelas VIII-1 dalam katagori rendah yaitu 40,74 \%. Adapun rincian dari ketercapaian tersebut adalah 10 siswa dengan persentase ketercapaian $100 \%$, 1 siswa dengan persentase ketercapaian $75 \%$, 1 siswa dengan ketercapaian $25 \%$, dan 15 siswa dengan persentase ketercapaian $0 \%$.

Indikator menyajikan konsep dalam bentuk representasi matematis merupakan kemampuan siswa dalam menuangkan konsep matematika secara sistematis dalam bentuk tabel, grafik, dan lainnya. Dari soal yang diberikan, secara garis besar tingkat menyajikan konsep dalam bentuk representasi matematis siswa kelas VIII-1 dalam katagori rendah yaitu 53,24 \%. Adapun rincian dari ketercapaian tersebut adalah 3 siswa dengan persentase ketercapaian 87,5 \%, 3 siswa dengan persentase ketercapaian $75 \%, 6$ siswa dengan ketercapaian $62,5 \%, 7$ siswa dengan persentase ketercapaian $50 \%$, 5 siswa dengan persentase ketercapaian 37,5\%, 1 siswa dengan persentase ketercapaian $25 \%$, dan 1 siswa dengan persentase ketercapaian $12,5 \%$. 


\section{Journal of Mathematics Science and Education \\ ISSN (Print) 2623-2375 | ISSN (Online) 2623-2383 | \\ DOI : https://doi.org/10.31540/jmse.v3i1.1037 \\ Penerbit : LP4MK STKIP PGRI Lubuklinggau}

Indikator mengembangkan syarat perlu dan syarat cukup suatu konsep merupakan kemampuan siswa dalam mengkaji suatu konsep dilihat dari sudut pandang konsep tersebut telah terpenuhi atapun telah tercukupi untuk dikatakan sebagai konsep. Dari soal yang diberikan, secara garis besar tingkat mengembangkan syarat perlu dan syarat cukup suatu konsep siswa kelas VIII-1 dalam katagori cukup yaitu $64,81 \%$. Adapun rincian dari ketercapaian tersebut adalah 16 siswa dengan persentase ketercapaian $100 \%$, 2 siswa dengan persentase ketercapaian $75 \%$, dan 9 siswa dengan persentase ketercapaian $0 \%$.

Indikator menggunakan, memanfaatkan dan memilih prosedur operasi tertentu merupakan kemampuan siswa dalam mengenali prosedur atau sejumlah langkah-langkah dari suatu permasalahan yang diberikan yang didalamnya terdapat proses perhitungan yang benar. Dari soal yang diberikan, secara garis besar tingkat mengembangkan syarat perlu dan syarat cukup suatu konsep siswa kelas VIII-1 dalam katagori rendah yaitu 40,28 \%. Adapun rincian dari ketercapaian tersebut adalah 4 siswa dengan persentase ketercapaian $100 \%, 3$ siswa dengan persentase ketercapaian $62,5 \%, 7$ siswa dengan persentase ketercapaian $50 \%, 3$ siswa dengan persentase ketercapaian $25 \%$, 6 siswa dengan persentase ketercapaian 12,5\%, dan 4 siswa dengan persentase ketercapaian $0 \%$.

Indikator mengaplikasikan konsep atau algoritma dalam pemecahan masalah merupakan kemampuan siswa dalam menggunakan suatu konsep yang telah diketahuinya untuk menyelesaikan suatu permasalahan. Dari soal yang diberikan, secara garis besar tingkat ketercapaian indikator mengaplikasikan konsep atau algoritma dalam pemecahan masalah siswa kelas VIII-1 dalam katagori cukup yaitu 66,20\%. Adapun rincian dari ketercapaian tersebut adalah 5 siswa dengan persentase ketercapaian $100 \%$, 2 siswa dengan persentase ketercapaian 87,5\%, 5 siswa dengan ketercapaian 75 $\%$, 5 siswa dengan persentase ketercapaian $62,5 \%, 5$ siswa dengan persentase ketercapaian $50 \%$, dan 4 siswa dengan persentase ketercapaian 37,5\%, dan 1 siswa dengan persentase ketercapaian 25\%. 


\section{KESIMPULAN}

Berdasarkan hasil analisis data penelitian tentang kemampuan pemahaman konsep siswa di kelas VIII-1 SMP Negeri 23 Rejang Lebong, peneliti menyimpulkan bahwa:

Dari hasil tes diagnosis kemampuan pemahaman konsep dapat diketahui bahwa subjek dengan kemampuan tinggi sebanyak 5 siswa dengan persentase 18,52\%, subjek dengan kemampuan sedang sebanyak 18 siswa dengan persentase 66,67 \%, dan subjek dengan kemampuan rendah sebanyak 4 siswa dengan persentase $14,81 \%$.

Sedangkan persentase ketercapaian setiap indikator kemampuan pemahaman konsep siswa secara keseluruhan terletak pada kriteria cukup sebesar 56,67\%. Dengan rincian tiap-tiap indikator pemahaman konsep sebagai berikut: 1) Indikator menyatakan ulang sebuah konsep sebesar $61,11 \%$, 2) Indikator memberikan contoh dan bukan contoh sebesar $80,56 \%, 3)$ Indikator mengklasifikasikan objek menurut sifat-sifat tertentu sesuai dengan konsepnya sebesar 40,74 \%, 4) Indikator menyajikan konsep dalam bentuk representasi matematis sebesar 53,24\%, 5) Indikator mengembangkan syarat perlu dan syarat cukup suatu konsep sebesar $64,81 \%, 6$ ) Indikator menggunakan, memanfaatkan dan memilih prosedur atau operasi tertentu sebesar 40,28 \%, dan 7) Indikator mengaplikasikan konsep atau algoritma dalam pemecahan masalah sebesar $66,20 \%$.

\section{DAFTAR RUJUKAN}

Andar dan Ikman. 2016. Deskripsi Kesalahan Siswa dalam Menyelesaikan Soal-Soal Ujian Semester Matematika Siswa Kelas VIII SMP Negeri 10 Kediri. Jurnal Penelitian Pendidikan Matematika. 4(2), 15-28

Fatqurhohman. 2016. Pemahaman Konsep Matematika Siswa dalam Menyelesaikan Masalah Bangun Datar. Jurnal Ilmiah Pendidikan Matematika. 4(2), 127-133

Hartati, dkk. 2017. Pengaruh Kemampuan Pemahaman Konsep, Kemampuan Komunikasi, dan Koneksi Matematika terhadap Kemampuan Pemecahan Masalah.

Hasratuddin. 2014. Pembelajaran Matematika Sekarang dan yang akan Datang Berbasis Karakter. Jurnal Didaktik. 1(2), 30-42

Lusiana, Restu, dkk. 2018. Analisis Pemahaman Konsep Siswa Kelas VII Berdasarkan Taksonomi Bloom Ditinjau dari Kemampuan Kognitif. JEMS Jurnal Edukasi Matematika dan Sains. 6(2), 60-69 


\section{Journal of Mathematics Science and Education \\ ISSN (Print) 2623-2375 | ISSN (Online) 2623-2383 | \\ DOI : https://doi.org/10.31540/jmse.v3i1.1037 \\ Penerbit : LP4MK STKIP PGRI Lubuklinggau}

Murizal, Angga, dkk. 2012. Pemahaman Konsep Matematis Model Pembelajaran Quantum Theaching. Jurnal Pendidikan Matematika. 1(1), 19-23

Raharjo, Jajo F. dan Herri Sulaiman. 2017. Mengembangkan Kemampuan Pemahaman Konsep Matematika Diskrit Dan Pembentukan Karakter Konstruktivis Mahasiswa Melalui Pengembangan Bahan Ajar Berbantuan Aplikasi Education Edmodo Bermodelkan Progresif Pace. Jurnal Teori dan Riset Matematika Teorema. 2(1), 47-62

Sari, Eka F.P. 2017. Pengaruh Kemampuan Pemahaman Konsep Matematika Mahasiswa Melalui Metode Pembelajaran Learning Starts With A Question Method. Jurnal Mosharafa. 6(1), 2534

Septiyana, Wieka, dkk. 2016. Model Pembelajaran Matematika Knisley untuk Meningkatkan Kemampuan Pemahaman Konseptual Matematis Siswa SMP. Jurnal Penelitian dan Pembelajaran Matematika. 9 (1), 128-137

Siyoto, Sandu dan Ali Sodik. 2015. Dasar Metodologi Penelitian. Yogyakarta; Literasi Media Publishing

Uno, Hamzah B. 2009. Model Pembelajaran: Menciptakan Proses Belajar Mengajar yang Kreatif daan Efektif. Jakarta; Bumi Aksara

Virgana. 2016. STAD Problem Solving Minat dan Pemahaman Konsep. Faktor Jurnal Ilmiah Kependidikan. 3(3), 297-308

Zuliana, Eka. 2017. Penerapan Inquiry Based Learning Berbantuan Peraga Manipulatif dalam Meningkatan Pemahaman Konsep Matematika pada Materi Geometri Mahasiswa PGSD Universitas Muria Kudus. Jurnal Pendidikan. 8(1), 35-43 